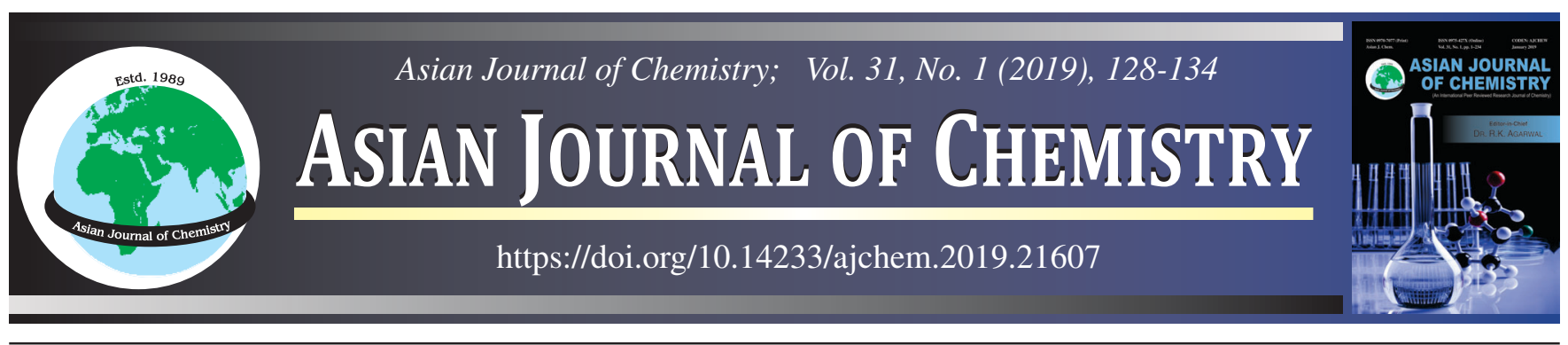

\title{
A Novel Method for Synthesis of 1,4-Dihydropyridines Using Robust Laterite Catalyst under Ultrasonic Irradiation
}

\author{
S.S. ChinE ${ }^{1}$ and C.S. PATIL ${ }^{2, *}$
}

${ }^{1}$ Department of Engineering Sciences, SRES' Sanjivani College of Engineering, Kopargaon-423601, India

${ }^{2}$ Department of Chemistry, Deogiri College, Aurangabad-431005, India

*Corresponding author: E-mail: chabu251962@yahoo.co.in

Received: 24 July 2018;

Accepted: 31 August 2018;

Published online: 30 November 2018;

AJC-19170

| An efficient method for the synthesis of 1,4-dihydropyridine derivatives from various aryl or heteroaryl aldehydes, $\beta$-ketoester and ammonium acetate in presence of laterite catalyst in ethanol under ultrasonication is reported. Catalyst study done with wet chemical analysis, FT-IR, XRD, SEM and EDS techniques. The catalyst can be recovered and reused without noticeable loss of activity even after five cycles.

Keywords: Laterite, Wet chemical analysis, Ultrasonication, Heterogeneous catalysis.

\section{INTRODUCTION}

1,4-Dihydropyridine (DHP) belongs to the class of nitrogen containing heterocycles and exhibits significant biological activities. Out of five regioisomers only 1,2-dihydropyridine and 1,4-dihydropyridine have gained significant attention because of their utility in the synthesis of various natural products [1]. 1,4-Dihydropyridine derivatives have been used as potential drug in the form of nifedipine, amlopdipine, isradipine, feldopine, nicardipine for the treatment of hypertension [2,3]. 1,4Dihydropyridines also act as antidepressive, hypnotic, antitubercular [4] and anticancer agent [5,6].

1,4-Dihydropyridines normally synthesized by Hantzsch method. 1,4-Dihydropyridine-3,5-dicarboxylates are called Hantzsch dihydropyridines or Hantzsch esters. It involves condensation of aryl aldehydes, $\beta$-ketoester and ammonium acetate or ammonia in presence of acetic acid or refluxing in alcohol $[7,8]$. This needs longer reaction time and gave low to reasonable yield of product [2,9]. Literature reveals that till today various attempts have been made to improve the Hantzsch synthesis using alternative catalyst and greener protocols [10].

These methods involves use of microwave [11,12], $\mathrm{Cu}(\mathrm{OTf})_{2}$ [13], hydrotalcites [14], $\mathrm{AlCl}_{3} \cdot 6 \mathrm{H}_{2} \mathrm{O}$ [2], silica/sulphuric acid [15], $\mathrm{Bi}\left(\mathrm{NO}_{3}\right)_{3} \cdot 5 \mathrm{H}_{2} \mathrm{O}$ [16], Y(OTf $)_{3}$ [17], nickel nanoparticles [18], silica gel-supported polyphosphoric acid $\left(\mathrm{PPA}^{\left.-\mathrm{SiO}_{2}\right)}\right.$ [19], L-proline [20], ionic liquids [21], ([BPy] $\left.\left[\mathrm{BF}_{4}\right]\right)$ [22], alumi- nium phosphate [23], diphenyl ammonium triflate [24], nano crystalline solid acid catalyst [25], melamine trisulfonic acid [26], visible light [27], eutectic solvent [28], perchloric acid resting on magnetic $\mathrm{Fe}_{3} \mathrm{O}_{4}$ nano-particles [29], graphene oxide nanoparticles [30], $\mathrm{CsCl}_{3} \cdot 7 \mathrm{H}_{2} \mathrm{O}$ [31], cerric ammonium nitrate [32], $\mathrm{Fe}_{2}\left(\mathrm{SO}_{4}\right)_{3} \cdot \mathrm{xH}_{2} \mathrm{O}$ [33], [Tb(mim) $] \mathrm{Cl}_{2} / \mathrm{AlCl}_{3}$ [34], benzyltriphenylphosphonium chloride (BTPPC) [35], $\mathrm{TiCl}_{4}$ [1], ultrasound irradiation [36], functionalize multi-walled carbon nanotube (MWCNTs) [37], etc. The most part of accessible methods of 1,4-dihydropyridines synthesis bear with drawbacks such as less yield, inconsiderate reaction conditions, expensive catalyst and long reaction time.

Hence, in context of green chemistry to develop novel catalytic scheme in an environmentally compassionate fashion is the real challenge to organic chemists. Therefore, we wish to report the synthesis of 1,4-dihydropyridines catalyzed by laterite clay under ultrasound irradiation. Laterite is abundantly available in nature and contains significant amount of $\mathrm{SiO}_{2}, \mathrm{Fe}_{2} \mathrm{O}_{3}$ and $\mathrm{Al}_{2} \mathrm{O}_{3}$, etc. It showed application as an adsorbent in the removal of heavy metal ions from waste water [38]. Recently, iron rich laterite has been reported as heterogeneous catalyst in the photo fenton process [39].

\section{EXPERIMENTAL}

All the chemicals used without further purification and were of AR grade. Ultrasonication was done in sonicator with a

This is an open access journal, and articles are distributed under the terms of the Creative Commons Attribution-NonCommercial 4.0 International (CC BY-NC 4.0) License, which allows others to copy and redistribute the material in any medium or format, remix, transform, and build upon the material, as long as appropriate credit is given and the new creations are licensed under the identical terms. 
frequency of $25 \mathrm{KHz}$. Synthesized products were characterized by IR, ${ }^{1} \mathrm{H}$ NMR and ${ }^{13} \mathrm{C}$ NMR spectroscopy data and melting points. Perkin Elmer spectrometer with ATR technology was used to record IR spectra. ${ }^{1} \mathrm{H}$ NMR and ${ }^{13} \mathrm{C}$ NMR spectra were recorded on $500 \mathrm{MHz}$ Bruker FT NMR spectrometer using $\mathrm{CDCl}_{3}$ solvent. Melting points were determined by an open capillary method and were uncorrected.

Catalyst preparation: In order to prepare catalyst the collected natural laterite sample was milled. It was then sieved through various mesh sizes to remove coarser particles and to get the particles with the average diameter $50 \mu \mathrm{m}$. The catalyst was then rinsed with distilled water. It was then dried and calcined at $300{ }^{\circ} \mathrm{C}$ for $3 \mathrm{~h}$. The screened catalyst was stored in polythene for further application. Chemical composition of collected laterite was calculated by wet chemical analysis method reported in Table-1.

TABLE-1

LATERITE COMPOSITION BY WET CHEMICAL ANALYSIS

\begin{tabular}{cc}
\hline Constituent & Laterite (\%) \\
\hline $\mathrm{SiO}_{2}$ & 47.17 \\
$\mathrm{Al}_{2} \mathrm{O}_{3}$ & 39.20 \\
$\mathrm{Fe}$ & 11.95 \\
$\mathrm{Mg}$ & 0.33 \\
\hline
\end{tabular}

Synthesis of 1,4-dihydropyridines: $\mathrm{In}$ a $50 \mathrm{~mL}$ round bottom flask aromatic/heteroaromatic aldehyde $(1 \mathrm{mmol})$, ethyl acetoacetate $(2 \mathrm{mmol})$, ammonium acetate $(1.5 \mathrm{mmol})$, in ethanol $(5 \mathrm{~mL})$, catalyst ( $20 \mathrm{wt} \%$ with respect to aldehyde) was added and the solution was sonicated for appropriate time. Advancement of reaction was observed by TLC. After completion of reaction the mixture was poured into cold water. Solid product was obtained by filtration and then purified by recrystallization (Scheme-I). The catalyst was recovered during recrystallization and reused without appreciable loss of activity up to six cycles. The elemental analysis of the synthesized compounds are shown in Table-2.

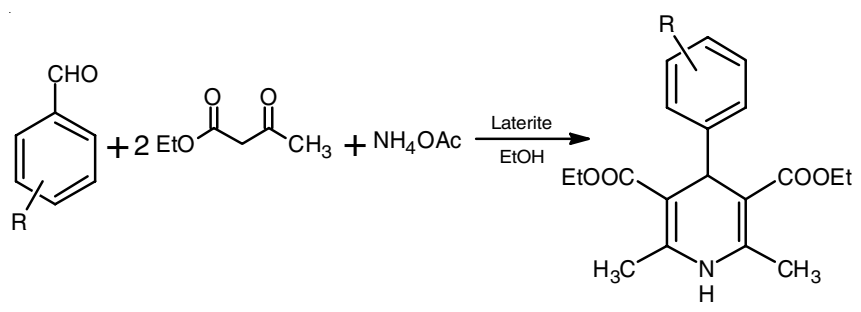

Scheme-I: Synthesis of 1,4-DHPs using laterite catalyst

\section{RESULTS AND DISCUSSION}

Catalyst has been characterized using XRD, FTIR, SEM and EDS techniques.

X-ray diffraction pattern analysis: This study was done in order to determine various minerals and inorganic phases present in laterite. X-ray diffraction study was carried out on Philips, Holland X-ray diffractometer. Fig. 1 represents XRD peaks of laterite sample. By correlating the results with JCPDS, laterite consists of $\mathrm{SiO}_{2}, \mathrm{Al}_{2} \mathrm{O}_{3}, \mathrm{Fe}_{2} \mathrm{O}_{3}, \mathrm{FeO}(\mathrm{OH})$ and $\mathrm{FeO}$. The diffraction peaks in this pattern at $2 \theta$ values $19,20.76,25.04$, 29.46, 35.16, 49, 53.81, 66.67 are associated with $\mathrm{SiO}_{2}$ and matches with literature values [39-41]. The diffraction peaks at $2 \theta 31^{\circ}, 33^{\circ}, 62.69^{\circ}, 64.23^{\circ}, 66^{\circ}$ represents $\mathrm{Al}_{2} \mathrm{O}_{3}$ and matches with (JCPDS 100425) $[38,42,43]$. The peaks at $2 \theta 24.25^{\circ}, 32^{\circ}$, $33.02^{\circ}, 67^{\circ}$ are due to presence of hematite phase $\left(\mathrm{Fe}_{2} \mathrm{O}_{3}\right)$ [38]. The diffraction peaks at $2 \theta 21^{\circ}, 26^{\circ}$ and at $2 \theta 36^{\circ}, 42^{\circ}, 61^{\circ}$ are related to $\mathrm{FeO}(\mathrm{OH})$ and $\mathrm{FeO}$, respectively [38].

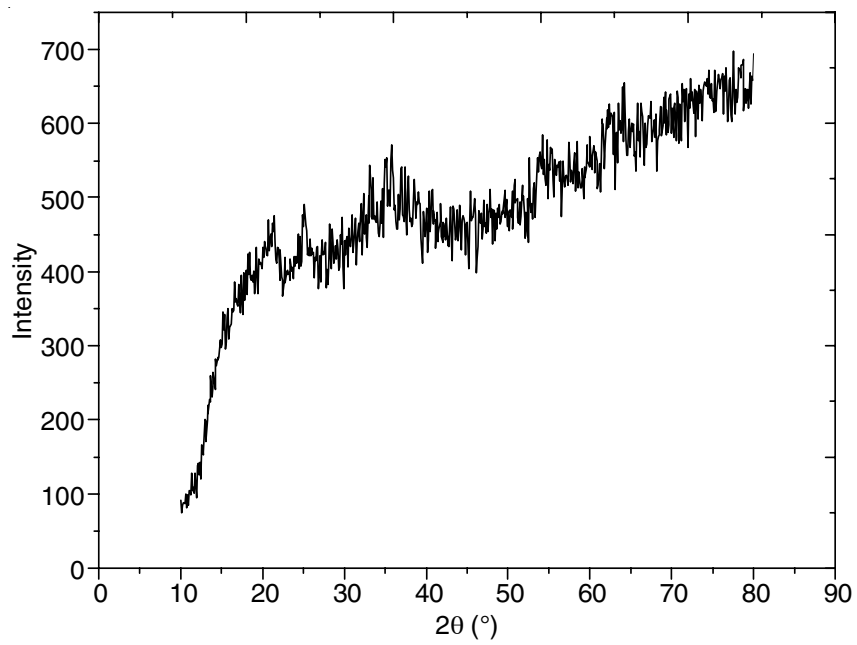

Fig. 1. XRD pattern of catalyst-laterite

Infrared spectroscopy (FT-IR): FT-IR study of catalyst was done to confirm presence of silica, iron and aluminum. The distinct band at 3694.7 and $3621 \mathrm{~cm}^{-1}$ indicate existence of isolated $\mathrm{OH}$ group of $\mathrm{Si}, \mathrm{Al}$. The band at $461.93 \mathrm{~cm}^{-1}$ indicates O-Si-O bending mode whereas band at 1029.51, 911.47 and $793.85 \mathrm{~cm}^{-1}$ signify occurrence of Si-O-Fe, Al$\mathrm{OH}, \mathrm{Fe}-\mathrm{OH}$ vibrations. The bands at 538.87, 469.43 and 450.09 $\mathrm{cm}^{-1}$ are due to $\mathrm{Fe}-\mathrm{O}$ bond stretching.

SEM and EDS: Scanning electron microscopy (SEM) and energy dispersive spectroscopy were performed in a JEOL

\begin{tabular}{|c|c|c|c|c|c|}
\hline \multirow{3}{*}{ Entry } & \multicolumn{4}{|c|}{$\begin{array}{c}\text { TABLE-2 } \\
\text { ELEMENTAL ANALYSIS OF SYNTHESIZED COMPOUNDS }\end{array}$} & \\
\hline & \multirow{2}{*}{ m.f. } & \multicolumn{4}{|c|}{ Elemental analysis (\%): Calcd. (Found) } \\
\hline & & $\mathrm{C}$ & $\mathrm{H}$ & $\mathrm{N}$ & $\mathrm{X}$ \\
\hline 1 & $\mathrm{C}_{19} \mathrm{H}_{21} \mathrm{NO}_{4} \mathrm{Cl}$ & $62.89(62.90)$ & $5.79(5.81)$ & $3.86(3.88)$ & $9.79(9.81)$ \\
\hline 2 & $\mathrm{C}_{20} \mathrm{H}_{24} \mathrm{NO}_{5}$ & $67.04(67.08)$ & $6.70(6.72)$ & $3.91(3.93)$ & - \\
\hline 3 & $\mathrm{C}_{19} \mathrm{H}_{25} \mathrm{NO}_{5}$ & $66.28(66.30)$ & $6.39(6.41)$ & $4.07(4.08)$ & - \\
\hline 4 & $\mathrm{C}_{19} \mathrm{H}_{21} \mathrm{~N}_{2} \mathrm{O}_{6}$ & $61.13(61.11)$ & $5.63(5.64)$ & $7.51(7.50)$ & - \\
\hline 5 & $\mathrm{C}_{19} \mathrm{H}_{22} \mathrm{NO}_{4}$ & $69.51(69.49)$ & $6.71(6.71)$ & $4.27(4.26)$ & - \\
\hline 6 & $\mathrm{C}_{19} \mathrm{H}_{21} \mathrm{NO}_{4} \mathrm{Br}$ & $55.03(55.07)$ & $5.16(5.16)$ & $3.44(3.45)$ & $19.64(19.66)$ \\
\hline 7 & $\mathrm{C}_{26} \mathrm{H}_{26} \mathrm{~N}_{3} \mathrm{O}_{4} \mathrm{~S}$ & $65.55(65.58)$ & $5.46(5.47)$ & $8.82(8.83)$ & $6.72(6.74)$ \\
\hline 8 & $\mathrm{C}_{28} \mathrm{H}_{27} \mathrm{~N}_{3} \mathrm{O}_{4} \mathrm{Cl}$ & $66.60(66.62)$ & $5.35(5.38)$ & $8.32(8.34)$ & $7.04(7.06)$ \\
\hline 9 & $\mathrm{C}_{29} \mathrm{H}_{30} \mathrm{~N}_{3} \mathrm{O}_{4}$ & $71.90(71.93)$ & $6.19(6.21)$ & $8.68(8.70)$ & - \\
\hline
\end{tabular}


$6360 \mathrm{~A}$ scanning electron microscope working at $20 \mathrm{kV}$, with an energy dispersive $\mathrm{X}$-ray spectrometer.

The SEM photographs of the laterite particles are shown in Fig. 2. The prepared particles were highly agglomerated with homogeneous distribution. Formation of agglomerated particles may arise due to calcinations. The surface appears like a "platelet" type of morphology, as shown in Fig. 2. The particles were of irregular shapes and different sizes.

All these characterization data clearly demonstrate morphology and composition of catalyst $[38,44]$.

Optimization of reaction conditions: Optimization of reaction conditions with respect to catalyst and solvent amount was investigated on selected model reaction of 4-chloro benzaldehyde $(1 \mathrm{mmol})$, ethyl acetoacetate $(2 \mathrm{mmol})$ and $\mathrm{NH}_{4} \mathrm{OAc}$ $(1.5 \mathrm{mmol})$. All reactions for optimization were performed under ultrasonication.

Optimization of catalyst amount: In the beginning reaction was performed without catalyst in presence of ethanol and only trace amount of product was obtained after $55 \mathrm{~min}$ (Table-3, entry1). The same reaction was done with $10 \mathrm{wt} \%$ of catalyst, $69 \%$ of product obtained after $40 \mathrm{~min}$ (Table-3, entry 2). As the catalyst amount increased from 10 to $20 \mathrm{wt} \%$ the time of reaction was reduced from 40 to $30 \mathrm{~min}$ and yield of product increased from 69 to $92 \%$. Further increase in the catalyst amount to $30 \mathrm{wt} \%$ no increase in yield of product

\begin{tabular}{cccc}
\multicolumn{5}{c}{ TABLE-3 } \\
OPTIMIZATION OF CATALYST AMOUNT \\
\hline Entry & Catalyst (wt \%) & Time (min) & ${\text { Yield }(\%)^{\mathrm{a}}}^{\text {Colm }}$ \\
\hline 1 & - & 55 & Trace \\
2 & 10 & 40 & 69 \\
3 & 20 & 30 & 92 \\
4 & 30 & 30 & 85 \\
\hline
\end{tabular}

${ }^{\mathrm{a}}$ Isolated yields

observed (Table-3, entry 4). From these observations $20 \mathrm{wt} \%$ of catalyst can be considered as optimized amount in $\mathrm{EtOH}$ as solvent.

Effect of solvent: We examined solvent effect on yield of product and time of reaction using several solvents. Initially reaction was performed without solvent and yields only $25 \%$ of product. Later on the same reaction was performed in presence of water, ethanol and then in toluene. It was found that comparatively ethanol is an efficient solvent which yields $92 \%$ product in short reaction time (Table- 4 ).

Synthesis of 1,4-dihydropyridines using laterite under ultrasonication: After the optimization of reaction conditions, we investigated the synthesis of 1,4-dihydropyridines using aryl/ heteroaryl aldehyde $(1 \mathrm{mmol})$, ethyl acetoacetate $(2 \mathrm{mmol})$ and ammonium acetate $(1.5 \mathrm{mmol})$ with $20 \mathrm{wt} \%$ catalyst in EtOH solvent under ultrasonic irradiation. From the results
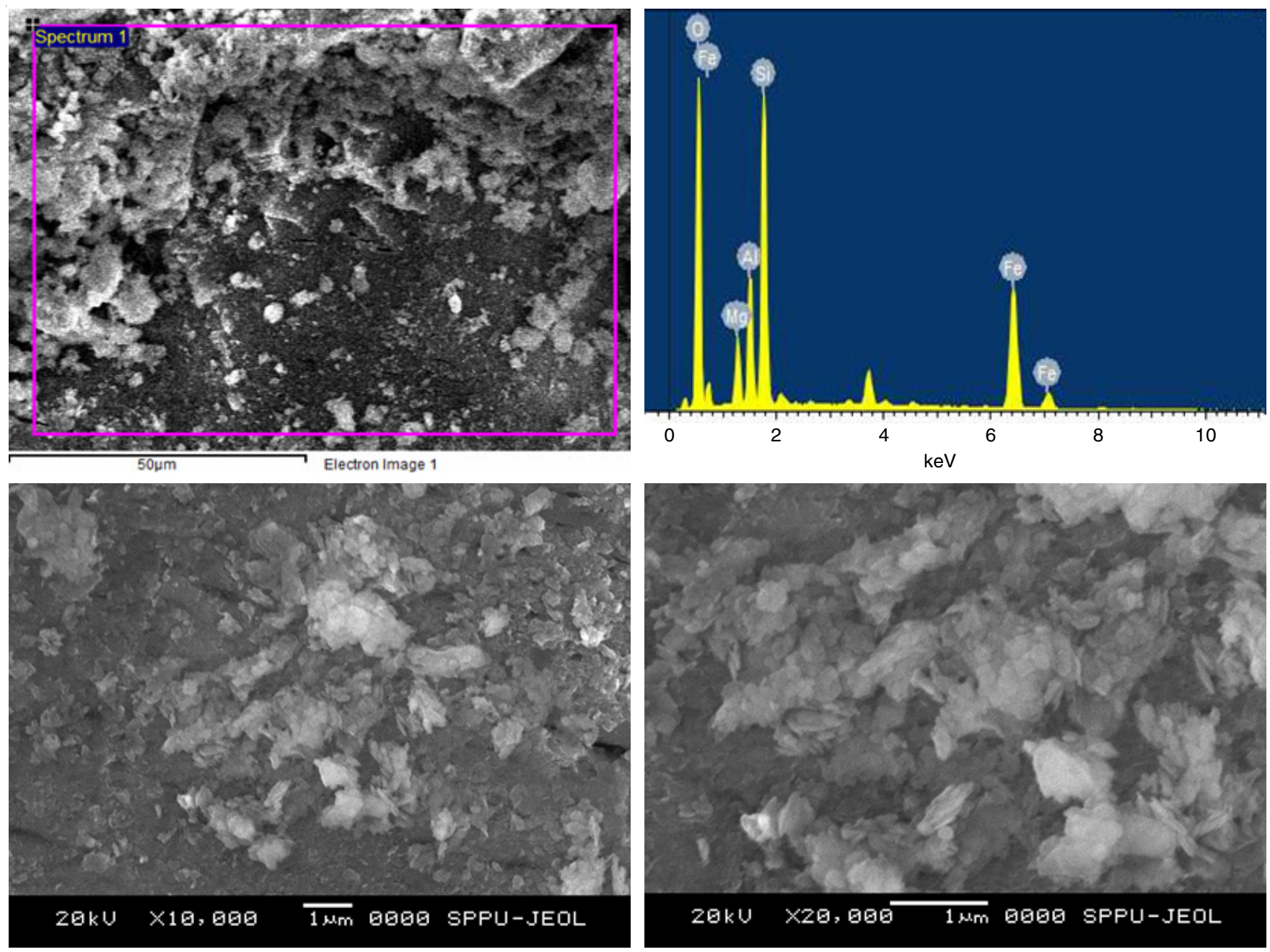

Fig. 2. SEM and EDS images of catalyst laterite 
TABLE-4

EFFECT OF SOLVENT ON PRODUCT YIELD AND REACTION TIME

\begin{tabular}{cccc}
\hline Entry & Solvent & Time $(\min )$ & ${\text { Yield }(\%)^{\mathrm{b}}}^{\mathrm{a}}$ \\
\hline 1 & - & 90 & 25 \\
2 & Water & 45 & 80 \\
3 & Ethanol & 30 & 92 \\
4 & Toluene & 55 & 65 \\
\hline
\end{tabular}

${ }^{\mathrm{a}}$ Model reaction in the presence of $20 \mathrm{wt} \%$ catalyst; ${ }^{\mathrm{b}}$ Isolated yields.

depicted in Table-5, products were obtained in good to excellent yields. It is also observed that the conversions including aldehydes with electron donating group complete in short reaction time than aldehydes with electron donating group.
Diethyl 1,4-dihydro-2,6-dimethyl-4-(1-phenyl-3-thiophene-2-yl)pyridine-3,5-dicarboxylate (entry 7): m.p.: 212 ${ }^{\circ} \mathrm{C}$; FTIR $\left(\mathrm{cm}^{-1}\right): 3319,1692,1635,1488,1299,1211,1096$, 961, 827, 757,694; ${ }^{1} \mathrm{H}$ NMR (500 MHz, $\mathrm{CDCl}_{3}, \delta$ ppm): 1.06 (bs,6H, $-\mathrm{CH}_{3}$ ), 2.21 (s, 6H, $-\mathrm{CH}_{3}$ ), 2.38 (s, 3H, Ar- $\mathrm{CH}_{3}$ ), 3.76 (bs, 2H, - $\mathrm{CH}_{2^{-}}$), 4.01 (bs, 2H, - $\mathrm{CH}_{2-}$ ), 5.28 (s, 1H, -CH-), 5.6 (s, 1H, -NH), 7.20-7.21 (m, 5H, Ar-H), 7.65-7.71 (m, 5H, Ar$\mathrm{H}) ;{ }^{13} \mathrm{C}$ NMR (100 MHz, $\left.\mathrm{CDCl}_{3}\right): 167.62,151.21,143.35$, $140.13,137.01,131.92,129.20,128.80,128.65,128.55$, 127.04, 125.89, 118.78, 104.44, 59.70, 29.65, 21.30, 19.47, 14.28.

Diethyl 4-(3-(4-chlorophenyl)-1-phenyl-1H-pyrazol-4yl)-1,4-dihydro-2,6-dimethyl pyridine-3,5-dicarboxylate

SYNTHESIS OF 1,4-DIHYDROPYRIDINES USING LATERITE UNDER ULTRASONICATION

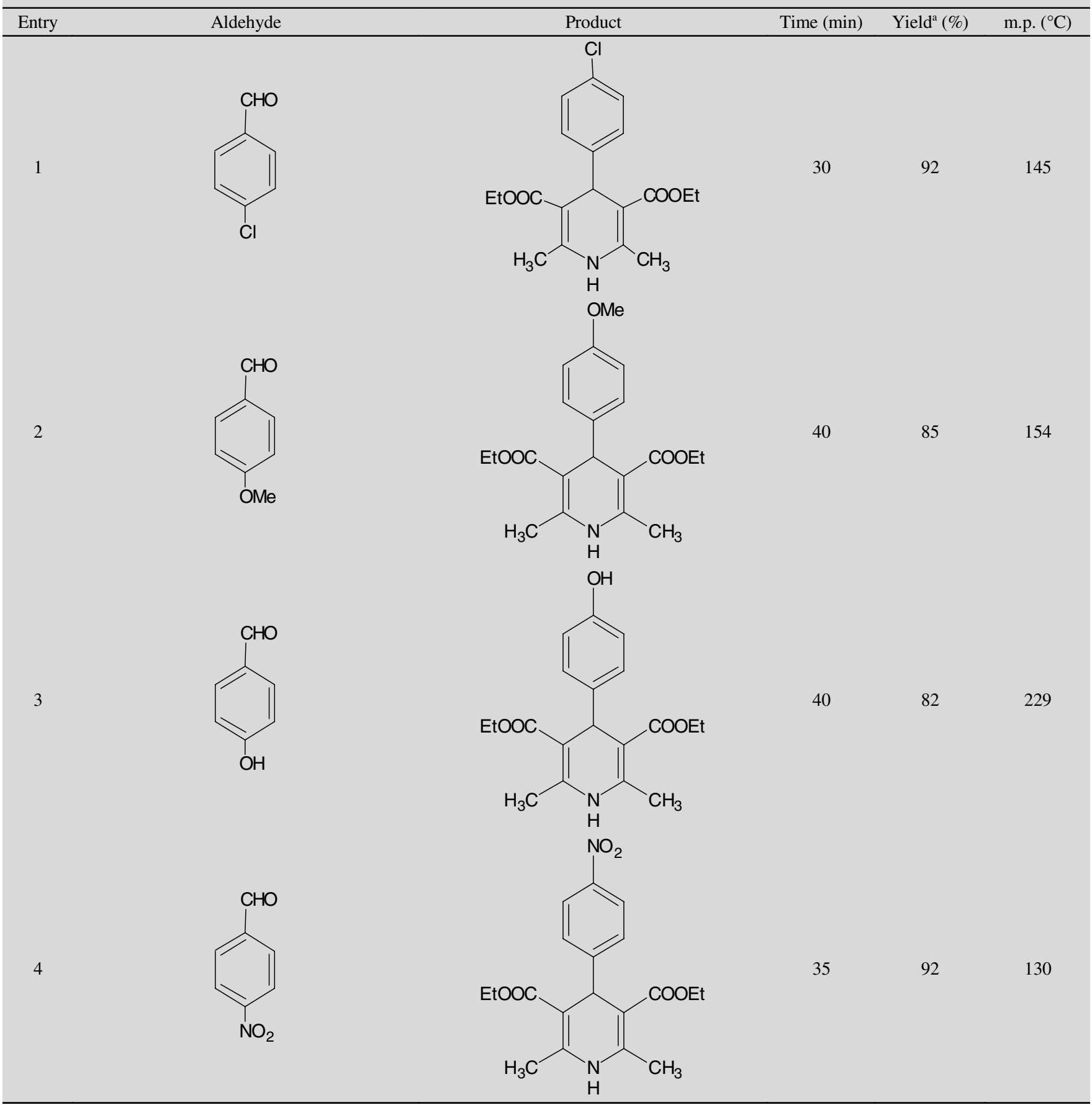


5<smiles>O=Cc1ccccc1</smiles>

6<smiles>O=Cc1ccc(Br)cc1</smiles>

7<smiles>O=Cc1cn(-c2ccccc2)nc1-c1cccs1</smiles>

8<smiles>O=Cc1cn(-c2ccccc2)nc1-c1ccc(Cl)cc1</smiles>

9<smiles>Cc1ccc(-c2nn(-c3ccccc3)cc2C=O)cc1</smiles><smiles>CCOC(=O)C1=C(C)NC(C)=C(C(=O)OCC)C1c1ccccc1</smiles>

Reaction condition: Aryl/hetero aryl aldehyde $(1.0 \mathrm{mmol})$, EAA $(2.0 \mathrm{mmol})$, ammonium acetate $(1.5 \mathrm{mmol})$ and catalyst $(20 \mathrm{wt} \%)$ in ethanol $(5$ $\mathrm{mL}$, Isolated yields. 
(entry 8): m.p.: $166^{\circ} \mathrm{C}$; FTIR $\left(\mathrm{cm}^{-1}\right): 3312,3092,1696,1632$, 1488, 1299, 1211, 1096, 962, 841, 758, 738,694; ${ }^{1} \mathrm{H}$ NMR (500 MHz, $\left.\mathrm{CDCl}_{3}, \delta \mathrm{ppm}\right): 1.06-1.09\left(\mathrm{t}, 6 \mathrm{H},-\mathrm{CH}_{3}\right), 2.26(\mathrm{~s}$, $\left.6 \mathrm{H},-\mathrm{CH}_{3}\right), 3.78-3.81\left(\mathrm{~m}, 2 \mathrm{H},-\mathrm{CH}_{2}\right), 4.01-4.04\left(\mathrm{~m}, 2 \mathrm{H},-\mathrm{CH}_{2}\right)$, $5.26(\mathrm{~s}, 1 \mathrm{H},-\mathrm{CH}-), 5.51(\mathrm{~s}, 1 \mathrm{H},-\mathrm{NH}), 7.23-7.26(\mathrm{t}, 1 \mathrm{H}, \mathrm{Ar}-\mathrm{H})$, 7.39-7.42 (t, 4H, Ar-H), 7.65-7.66 (d, 2H, Ar-H), 7.73 (s, 1H, $\mathrm{ArH}), 7.84-7.86(\mathrm{~d}, 2 \mathrm{H}, \mathrm{Ar}-\mathrm{H}) ;{ }^{13} \mathrm{C} \mathrm{NMR}\left(100 \mathrm{MHz}, \mathrm{CDCl}_{3}\right)$ : $167.47,149.82,143.29,139.99,130.40,130.24,129.27$, $128.86,128.07,127.37,126.18,118.87,104.56,59.81,29.68$, $19.63,14.31$.

Diethyl 1,4-dihydro-2,6-dimethyl-4-(1-phenyl-3-ptolyl-1H-pyrazol-4-yl)pyridine-3,5-dicarboxylate (entry 9): m.p.: $180{ }^{\circ} \mathrm{C}$; FTIR $\left(\mathrm{cm}^{-1}\right)$ : 3312, 1696, 1648, 1486, 1368, 1304, 1204, 1095, 961, 878, 822, 82, 754, 720, 686; ${ }^{1} \mathrm{H}$ NMR $\left(500 \mathrm{MHz}, \mathrm{CDCl}_{3}, \delta \mathrm{ppm}\right): 1.22-1.25\left(\mathrm{t}, 6 \mathrm{H},-\mathrm{CH}_{3}\right), 2.08(\mathrm{~s}$, $\left.6 \mathrm{H},-\mathrm{CH}_{3}\right), 4.09-4.11\left(\mathrm{~m}, 4 \mathrm{H},-\mathrm{CH}_{2}\right), 5.8(\mathrm{~s}, 1 \mathrm{H},-\mathrm{CH}-), 5.14$ (s, 1H, -NH), 7.19-7.21 (d, 1H, Ar-H), 7.24-7.27 (t, 2H, ArH), 7.40-7.43 (t, 2H, Ar-H), 7.48-7.49 (d, 1H, Ar-H), 7.657.66 (d, 2H, Ar-H), 7.84 (s, 1H, Ar-H); ${ }^{13} \mathrm{C}$ NMR (100 MHz, $\mathrm{CDCl}_{3}$ ): 167.30, 157.04, 155.06, 143.64, 139.89, 134.39, $131.07,130.24,129.36,30.43,19.42,14.41$

Recycling study of laterite catalyst: The recycling of heterogeneous catalyst was studied by separation of catalyst during recrystallization. It was washed with distilled water, dried and calcined. The recovered catalyst was examined under optimized reaction conditions. From the recycling experiments, the catalyst can be reused without appreciable loss of activity even after five cycles (Fig. 3).

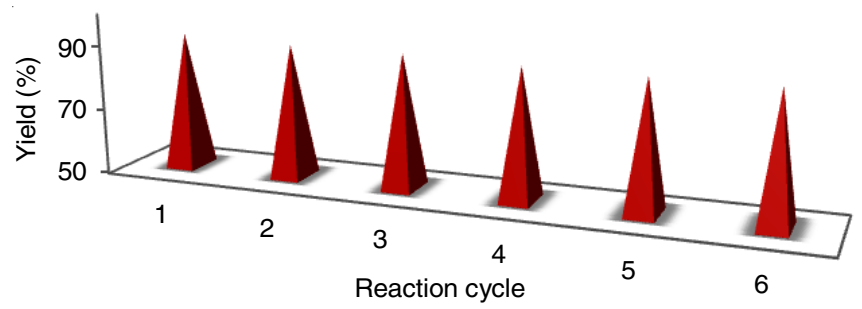

Fig. 3. Recycling of catalyst

\section{Conclusion}

We have developed nonconventional, greener synthetic protocol for synthesis of 1,4-dihydropyridines using robust laterite catalyst under ultrasonic irradiation at room temperature. Laterite catalyst was prepared by simple procedure and it could be recycled for at least six cycles without appreciable loss of reactivity. The significant features of this protocol are use of naturaly available, inexpensive, reusable, efficient catalyst, sonication, short reaction time and good to excellent yields of product.

\section{ACKNOWLEDGEMENTS}

The authors are grateful to The Principal S.R.E.S', Sanjivani College of Engineering, Kopargaon and Principal Deogiri College, Aurangabad, India for providing necessary research amenities and constant encouragement.

\section{CONFLICT OF INTEREST}

The authors declare that there is no conflict of interests regarding the publication of this article.

\section{REFERENCES}

1. V.K. Sharma and S.K. Singh, RSC Adv., 7, 2682 (2017); https://doi.org/10.1039/C6RA24823C.

2. S. Das Sharma, P. Hazarika and D. Konwar, Catal. Commun., 9, 709 (2008); https://doi.org/10.1016/j.catcom.2007.08.008.

3. M. Litvic, I. Cepanec, M. Filipan, K. Kos, A. Bartolinèic, V. Druškovic, M. Majed Tibi and V. Vinkovic, Heterocycles, 65, 23 (2005); https://doi.org/10.3987/COM-04-10194.

4. R. Mannhold, B. Jablonka, W. Voigt, K. Schönafinger and E. Schraven, Eur. J. Med. Chem., 27, 229 (1992); https://doi.org/10.1016/0223-5234(92)90006-M.

5. R.K. Singh, D.N. Prasad and T.R. Bhardwaj, Med. Chem. Res., 24, 1534 (2015); https://doi.org/10.1007/s00044-014-1236-1.

6. H.-A.S. Abbas, W.A. El-Sayed and N.M. Fathy, Eur. J. Med. Chem., 45, 973 (2010);

https://doi.org/10.1016/j.ejmech.2009.11.039.

7. A. Hantzsch, J. Leibigs Ann. Chem., 215, 1 (1882); https://doi.org/10.1002/jlac.18822150102.

8. B. Loev and K.M. Snader, J. Org. Chem., 30, 1914 (1965); https://doi.org/10.1021/jo01017a048.

9. A. Dondoni, A. Massi, E. Minghini and V. Bertolasi, Tetrahedron, 60, 2311 (2004); https://doi.org/10.1016/j.tet.2004.01.011.

10. S.B. Sapkal, K.F. Shelke, B.B. Shingate and M.S. Shingare, Tetrahedron Lett., 50, 1754 (2009);

https://doi.org/10.1016/j.tetlet.2009.01.140.

11. A. Agarwal and P.M.S. Chauhan, Tetrahedron Lett., 46, 1345 (2005); https://doi.org/10.1016/j.tetlet.2004.12.109.

12. Mithlesh, P. Pareek, R. Kant, S.K. Shukla and K.G. Ojha, Cent. Eur. J. Chem., 8, 163 (2010);

https://doi.org/10.2478/s11532-009-0114-Z.

13. A.S. Paraskar and A. Sudalai, Indian J. Chem., 46B, 331 (2007).

14. C.A. Antonyraj and S. Kannan, Appl. Catal. A Gen., 338, 121 (2008); https://doi.org/10.1016/j.apcata.2007.12.028.

15. B. Datta and M.A. Pasha, Chin. J. Catal., 32, 1180 (2011); https://doi.org/10.1016/S1872-2067(10)60252-5.

16. D. Bandopadhyay, S. Maldonado and B.K. Banik, Molecules, 17, 2643 (2012); https://doi.org/10.3390/molecules 17032643 .

17. J. Ramchander, G. Raju, N. Rameshwar, T.S. Reddy and A.R. Reddy, Spectrochim. Acta A Mol. Biomol. Spectrosc., 85, 210 (2012); https://doi.org/10.1016/j.saa.2011.09.062.

18. L. Saikia, D. Dutta and D.K. Dutta, Catal. Commun., 19, 1 (2012); https://doi.org/10.1016/j.catcom.2011.12.013.

19. A. Khojastehnezhad, F. Moeinpour and A. Shams, Synth. React. Inorg., 42, 273 (2012); https://doi.org/10.1080/15533174.2011.609858.

20. C.L. Shi, H. Chen and D.Q. Shi, J. Heterocycl. Chem., 49, 125 (2012); https://doi.org/10.1002/jhet.782.

21. B. Jahanbin, A. Davoodnia, H. Behmadi and N. Tavakoli-Hoseini, Bull. Korean Chem. Soc., 33, 2140 (2012); https://doi.org/10.5012/bkcs.2012.33.7.2140.

22. X.Y. Wu, Synth. Commun., 42, 454 (2012); https://doi.org/10.1080/00397911.2010.525773.

23. K. Purandhar, V. Jyothi, P.P. Reddy, M.A. Chari and K. Mukkanti, J. Heterocycl. Chem., 49, 232 (2012); https://doi.org/10.1002/jhet.793.

24. J. Li, P. He and Ch. Yu, Tetrahedron, 68, 4138 (2012); https://doi.org/10.1016/j.tet.2012.03.104.

25. A. Teimouri, L. Ghorbanian and A. Moatari, Bull. Chem. Soc. Ethiop., 27, 427 (2013).

26. S.S. Mansoor, K. Aswin, K. Logaiya and S.P.N. Sudhan, J. King Saudi Univ. Sci., 25, 191 (2013); https://doi.org/10.1016/j.jksus.2013.02.001.

27. S. Ghosh, F. Saikh, J. Das and A.K. Pramanik, Tetrahedron Lett., 54, 58 (2013);

https://doi.org/10.1016/j.tetlet.2012.10.079.

28. S. Pednekar, R. Bhalerao and N. Ghadge, J. Chem. Sci., 125, 615 (2013); https://doi.org/10.1007/s12039-013-0399-5. 
29. B. Dam, S. Nandi and A.K. Pal, Tetrahedron Lett., 55, 5236 (2014); https://doi.org/10.1016/j.tetlet.2014.08.002.

30. R.P. Kagne, G.H. Nikam, V.G. Kalalawe, S.N. Niwadange and D.R. Munde, J. Chem. Chem. Sci, 7, 1064 (2017).

31. G. Sabitha, K. Arundhathi, K. Sudhakar, B.S. Sastry and J.S. Yadav, Synth. Commun., 39, 2843 (2009); https://doi.org/10.1080/00397910802656091.

32. S. Ko and C.F. Yao, Tetrahedron, 62, 7293 (2006); https://doi.org/10.1016/j.tet.2006.05.037.

33. K. Islam, D.K. Das and A.T. Khan, Tetrahedron Lett., 55, 5613 (2014); https://doi.org/10.1016/i.tetlet.2014.08.067.

34. B.P. Reddy, K. Rajesh and V. Vijayakumar, Arab. J. Chem., 8, 138 (2015); https://doi.org/10.1016/j.arabjc.2011.01.027.

35. M. Alikarami and M. Ghosemian, Bulg. Chem. Commun., 48, 373 (2016).

36. X.S. Wang, Z.Y. Li, J.C. Zhang and J.T. Li, Ultrason. Sonochem., 15, 677 (2008);

https://doi.org/10.1016/j.ultsonch.2008.02.009.

37. L. Moradi and M. Zare, Green Chem. Lett. Rev., 11, 197 (2018); https://doi.org/10.1080/17518253.2018.1458160.
38. S. Mitra, L.S. Thakur, V.K. Rathore and P. Mondal, Desalination Water Treat., 57, 18406 (2015); https://doi.org/10.1080/19443994.2015.1088806.

39. A. Khataee, F. Salahpour, M. Fathinia, B. Seyyedi and B. Vahid, J. Ind. Eng. Chem., 26, 129 (2015); https://doi.org/10.1016/j.jiec.2014.11.024.

40. H. Yahya, M.R. Othman and Z.A. Ahmad, Procedia Chem., 19, 922 (2016); https://doi.org/10.1016/j.proche.2016.03.136.

41. L. Deng, Q. Xu and H. Wu, Procedia Environ. Sci., 31, 662 (2016); https://doi.org/10.1016/j.proenv.2016.02.122.

42. S. Ghanaraja, K.L.V. Kumar, H.P. Raju and K.S. Ravikumar, Mater. Today Proc., 2, 1291 (2015); https://doi.org/10.1016/j.matpr.2015.07.045.

43. C. Liu, Z. Zhou, Y. Huang, Z. Cheng and W. Yuan, Chin. J. Chem. Eng., 22, 383 (2014); https://doi.org/10.1016/S1004-9541(14)60038-0.

44. A. Maiti, B.K. Thakur, J.K. Basu and S. De, J. Hazard. Mater, 262, 1176 (2013);

https://doi.org/10.1016/j.jhazmat.2012.06.036. 